
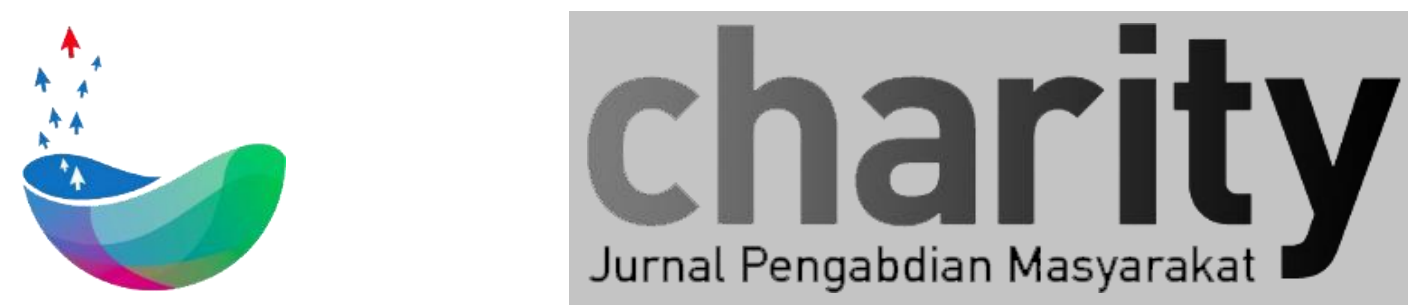

\title{
Pembuatan UV-C-Locker untuk Sterilisasi Barang Pengunjung di RSUD Kesehatan Kerja Jabar
}

Rini Handayani ${ }^{1, *}$, Marlindia Ike Sari ${ }^{2}$, Tedi Gunawan ${ }^{3}$, Kristina Sisilia ${ }^{4}$, Syahputra ${ }^{5}$, Syarifuddin ${ }^{6}$, Devie Ryana Suchendra ${ }^{7}$, Anak Agung Gde Agung ${ }^{8}$, Arry Widodo ${ }^{9}$, Roni Riandi ${ }^{10}$

\footnotetext{
1,2,3,7, Program Studi Teknologi Komputer, Fakultas Ilmu Terapan, Universitas Telkom

4,5,6,9 Program Studi Administrasi Bisnis, Fakultas Komunikasi dan Bisnis, Universitas Telkom

${ }^{8}$ Program Studi Sistem Informasi Akuntansi, Fakultas Ilmu Terapan, Universitas Telkom

${ }^{10}$ Fakultas Ilmu Terapan, Universitas Telkom
}

* rini.handayani@telkomuniversity.ac.id

\section{INFO ARTIKEL}

Diterima 11 Januari 2021

Direvisi 09 November 2021

Disetujui 06 Desember 2021

Tersedia Online 04 Februari 2022

Keyword: Pandemi, Covid-19, Sterilisasi, UV-C

\begin{abstract}
ABSTRAK
Pada masa pandemi Covid-19, kebersihan dan sterilisasi barang bawaan menjadi sorotan utama. Saat PSBB (Pembatasan Sosial Berskala Besar) maupun pada masa new normal, setiap orang dan tempat harus terjaga kesterilannya. Setiap orang harus melakukan protokol kesehatan seperti penggunaan masker, mencuci tangan menggunakan air dan sabun maupun menggunakan hand sanitizer, dan setiap barang yang dibawa juga harus dilakukan sterilisasi. Ramainya pengunjung pada RSUD Kesehatan Kerja merupakan potensi pertumbuhan ekonomi yang positif sekaligus ancaman penyebaran virus SARS-CoV2, penyebab Covid-19. Sterilisasi barang bawaan pengunjung dan pasien diharapkan dapat menekan penyebaran virus ini sehingga aktifitas dapat tetap berlanjut dengan tetap memperhatikan protokol kesehatan. Namun, sterilisasi dengan air dan sabun atau media alcohol seperti hand sanitizer dinilai tidak praktis, terutama untuk barang berukuran besar atau barang yang tidak dapat terkena cairan, seperti dokumen. Cara ini juga tidak efisien karena membutuhkan waktu yang relatif lama dalam proses sterilisasinya. Salah satu cara sterilisasi yang efektif dan efisien adalah menggunakan sinar UVC, yang mampu membunuh virus hingga $99 \%$ dan membutuhkan waktu yang singkat. Untuk itu, dalam kegiatan ini dibuat loker sterilisasi satu tingkat dan dua tingkat dengan menggunakan lampu UV-C.
\end{abstract}

Korespondensi:

Fakultas Ilmu Terapan, Universitas Telkom

Jl. Telekomunikasi No. 1, Terusan Buah Batu, Bandung, 40257

Indonesia

E-mail: rini.handayani@telkomuniversity.ac.id

ORCID ID:

Penulis Pertama: Rini Handayani

https://doi.org/xxx 
Paper_reg_number xxx (C) The Authors. Published by Directorate of Research and Community Service, Telkom University.

This is an open access article under the xxx license (https://creativecommons.org/licenses/xxx)

\section{Pendahuluan}

Rumah Sakit Umum Daerah Kesehatan Kerja (RSUD-KK) berdiri sejak tahun 1992 (Gambar 1), dengan konsep bentuk pelayanan kesehatan pada pekerja yang dibangun di kab/kota sentra industry di Jawa Barat dengan nama Pelayanan Kesehatan Tenaga Kerja (PKTK) [1]. Badan ini kemudian mengalami perkembangan dalam pelayanan hingga pada tahun 2017 melalui Gubernur Jawa Barat menjadikan badan ini sebagai Rumah sakit dengan unggulan Pelayanan Kesehatan Kerja (Occupational Health Service).
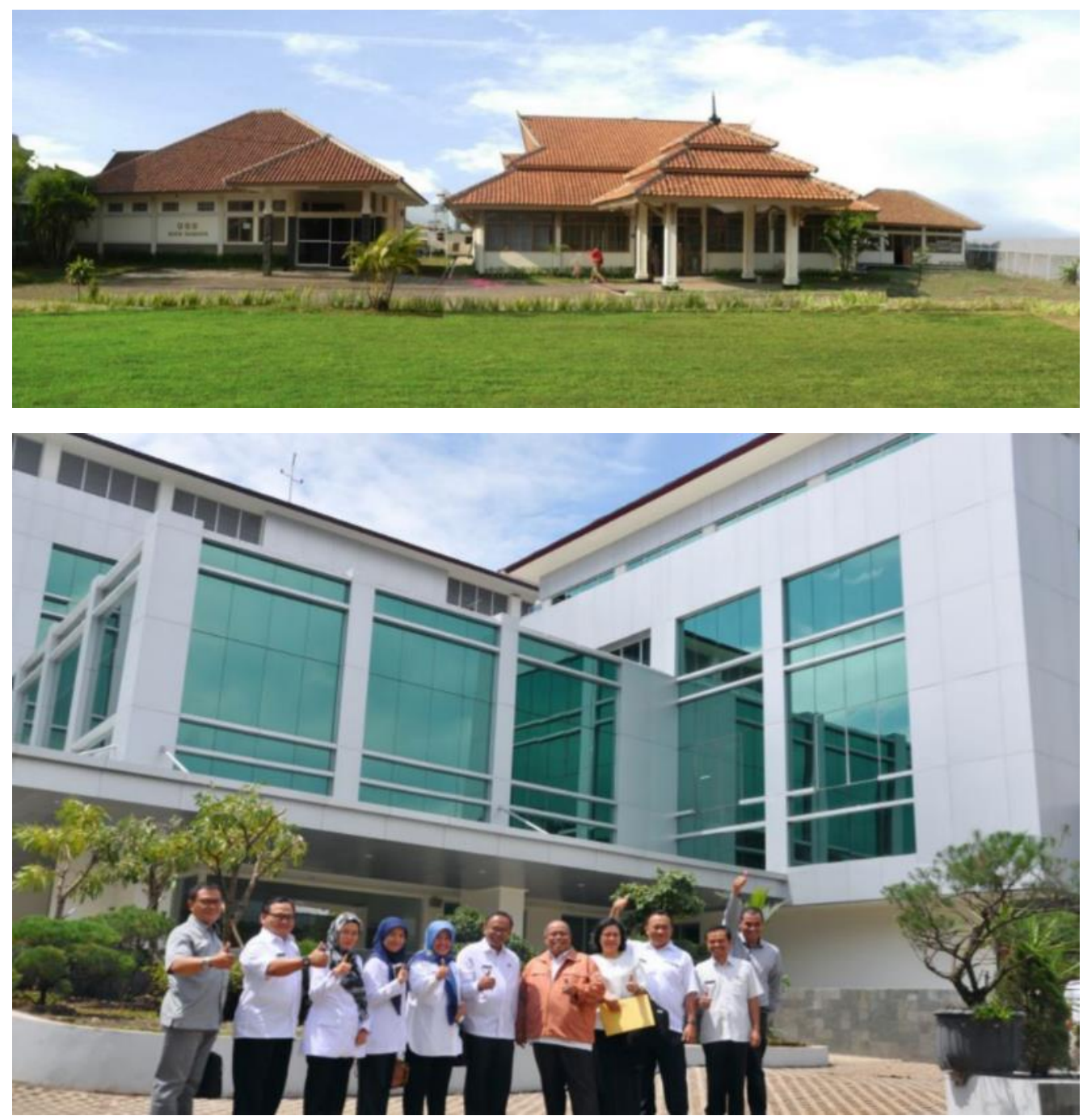

Gambar 1. RSUD Kesehatan Kerja Provinsi Jawa Barat (Dulu dan Sekarang)

RSUD Kesehatan Kerja Provinsi Jawa Barat merupakan rumah sakit pertama dan satusatunya di Jawa Barat dan di Indonesia yang menyelenggarakan pelayanan kesehatan rujukan yang komprehensif dan holistik, berkualitas dengan unggulan kesehatan kerja. 
Frekuensi kunjungan pasien tiap bulan rata-rata mencapai dua ribuan pengunjung dan penyakit yang paling sering dikeluhkan adalah infeksi saluran pernapasan akut (ISPA) sebanyak 957 kasus (Gambar 2).
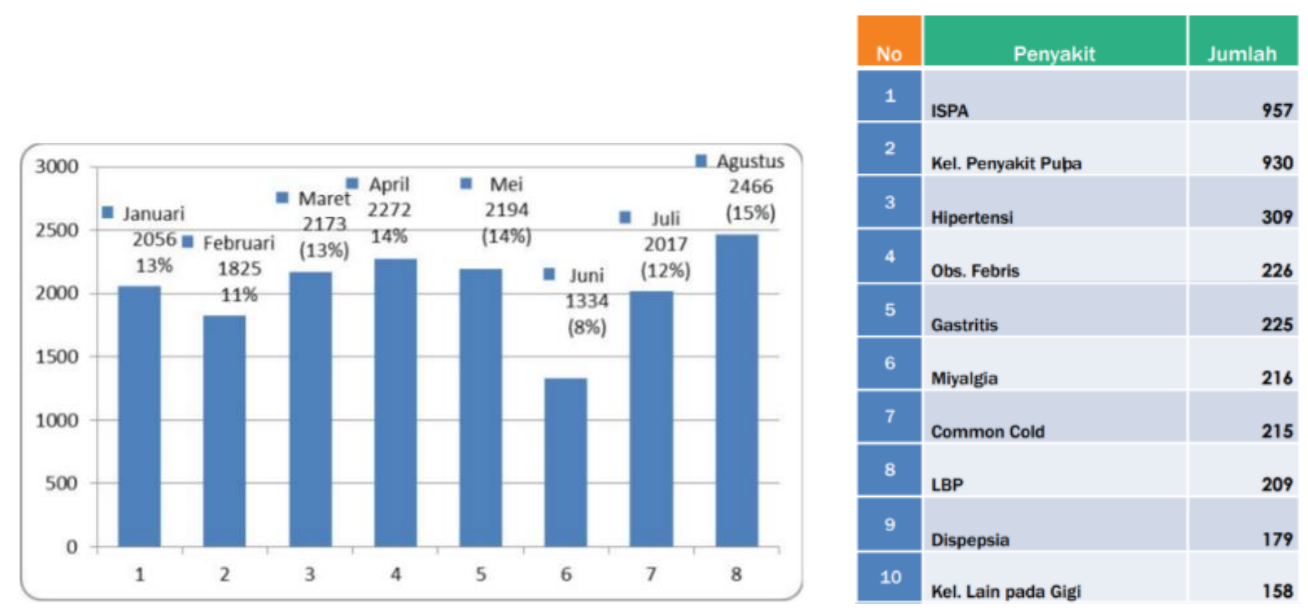

Gambar 2. Jumlah Kunjungan per Bulan dan Penyakit Terbanyak

\section{Permasalahan dan Solusi yang Ditawarkan}

Pada masa pandemi Covid-19, kebersihan diri dan barang bawaan mendapat perhatian lebih. Setiap orang harus melakukan protokol kesehatan seperti menggunakan masker, mencuci tangan, dan bertanggungjawab atas setiap barang bawaannya. Masa new normal tidak dapat terelakkan karena situasi ekonomi yang kian mendesak dan roda perekonomian harus berputar. Mobilitas masyarakat diprediksi akan mengalami peningkatan pada masa new normal [2]. Begitu juga pengunjung rumah sakit. Berbagai macam cara sterilisasi guna menjalankan protokol kesehatan juga diupayakan seperti:

a. mencuci tangan dan barang-barang dengan sabun dan air mengalir,

b. mencuci tangan dan/atau menyemprot barang-barang dengan larutan alcohol minimal $70 \%$,

c. menyemprot permukaan barang dengan larutan disinfektan ataupun antiseptic,

d. penyinaran ruangan dan material dengan sinar UV-C (tidak boleh terkena manusia karena akan berakibat fatal) [3]

e. dan lain sebagainya

Walaupun mencuci dengan sabun dan air mengalir adalah cara yang paling efektif namun cara ini dinilai kurang praktis apabila diaplikasikan pada barang-barang yang sering dibawa pengunjung rumah sakit seperti tas, jaket, topi, kacamata, dan lain 
sebagainya. Hal ini dikarenakan virus Corona memiliki ketahanan yang berbeda-beda dalam penempelan pada berbagai jenis permukaan. [4], sehingga terdapat banyak barang yang harus disterlkan. Dan tidak semua permukaan dapat dilakukan pencucian dengan air. Penggunaan sinar UV-C sebagai metode sterilisasi dinilai paling praktis dan efektif [5][7]. Kendalanya, perangkat sterilisasi dengan menggunakan UV-C ini belum ada yang tersedia dengan harga terjangkau yang memuat kapasitas besar di pasaran.

\section{Metode Pelaksanaan dan Gambaran IPTEKS yang Ditransfer}

\subsection{Metode Pelaksanaan, Tahapan dan Bentuk Kegiatan Pengabdian kepada Masyarakat}

Metode dan tahapan kegiatan ini terdiri dari tiga metode diantaranya:
a. Melakukan analisa perilaku dari user (user experience)
b. Pembuatan UV-C locker
c. Pendampingan kepada mitra secara daring

Bentuk kegiatan pengabdian kepada masyarakat ini terdiri dari tiga bentuk kegiatan yaitu:

a. Pengamatan langsung pada user experience di RSUD-KK

b. Pembuatan UV-C locker disesuiakan dengan kebutuhan dan permasalahan pengguna

c. Sosialisasi dan edukasi teknis penggunaan UV-C locker di RSUD-KK

\subsection{Gambaran IPTEKS yang ditransfer}

IPTEK yang diberikan kepada RSUD-KK sebagai mitra pada kegiatan pengabdian masyarakat adalah sebagai berikut. Adapun gambaran IPTEKS lengkap dapat dilihat pada Gambar 3.

a. Pembuatan UV-C locker

b. Penyuluhan penggunan UV-C locker 


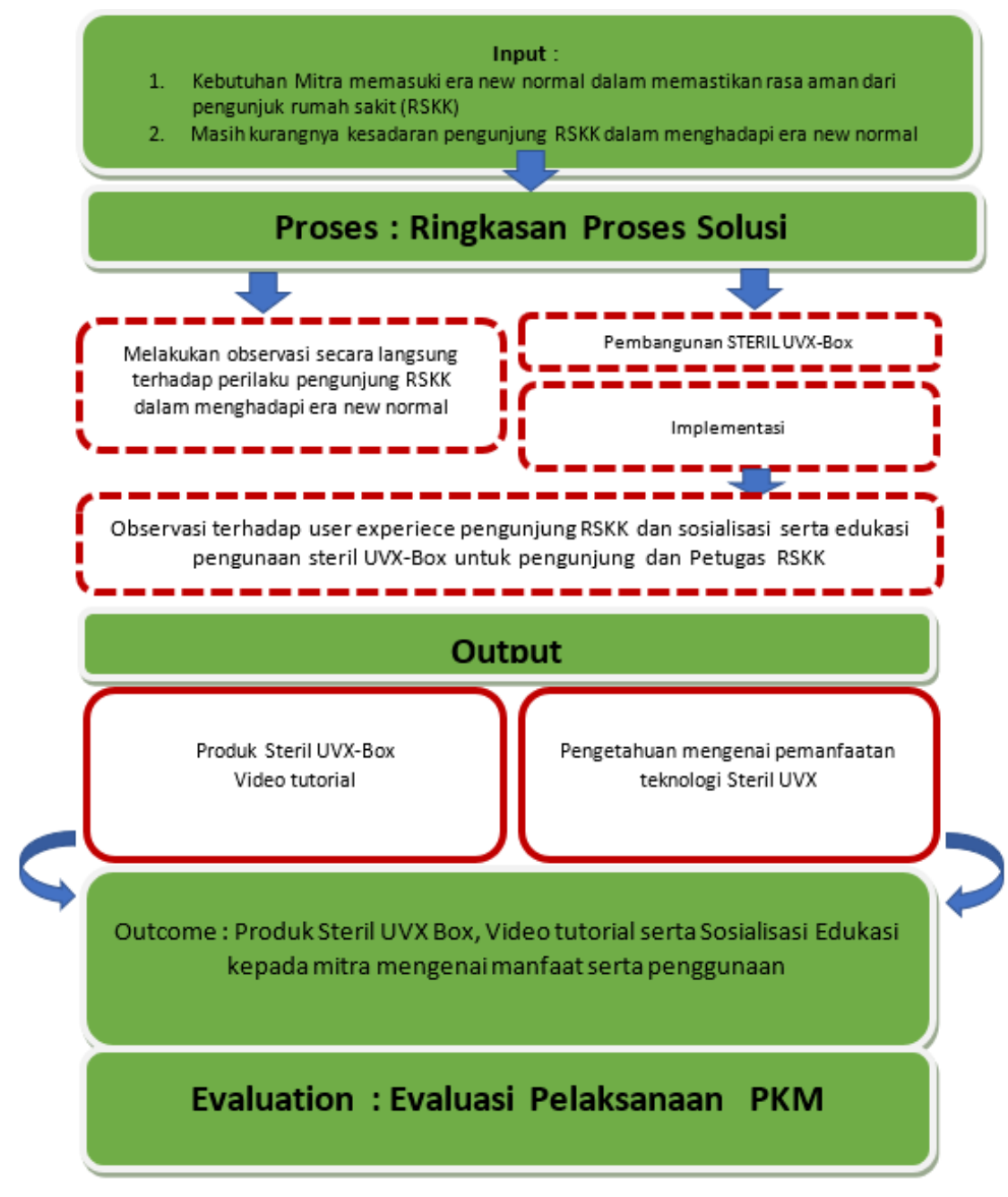

Gambar 3. Gambaran IPTEK yang Ditransfer pada Masyarakat Sasar

\subsection{Pembuatan UV-C Box Sterilization}

Pembuatan loker sterilisasi ini merupakan salah satu contoh implementasi bidang embedded system, khususnya microelectronic dalam kehidupan sehari-hari. Penggunaan sensor dan microcontroller memungkinkan otomatisasi perangkat dan meminimalisir kontak, sehingga diharapkan dapat mempermudah penggunaan perangkat. Alur kerja sistem dapat dilihat pada flowchart yang ditunjukkan pada Gambar 4.

Bagian dalam dari locker dilapisi dengan aluminium foil, bertujuan agar cahaya dapat menjangkau seluruh bagian barang yang dimasukkan. Waktu penyinaran selama du ament dianggap cukup untuk membunuh kuman pada permukaan benda yang dimasukkan, namun pengguna tetap harus mewaspadai benda yang terdapat pada area yang tidak terkena sinar, seperti bagian dalam dari tas [8]. 


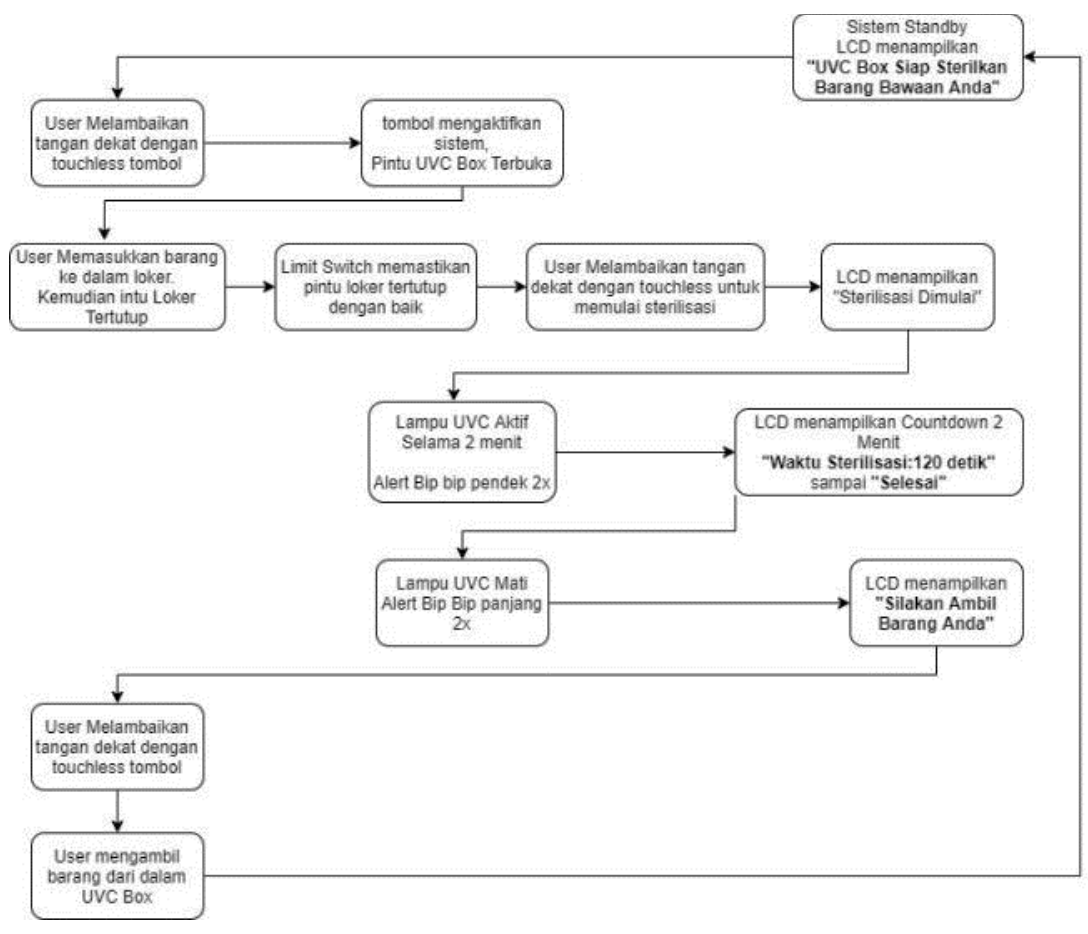

Gambar 4. Flowchart Sistem

Loker yang dibangun menggunakan sistem touchless, sehingga meminimalisir kontak fisik pada alat. Pada Gambar 5 dan Gambar 6 merupakan hasil akhir dari pembuatan loker sterilisasi, yang terdiri dari loker satu tingkat dan loker dua tingkat.

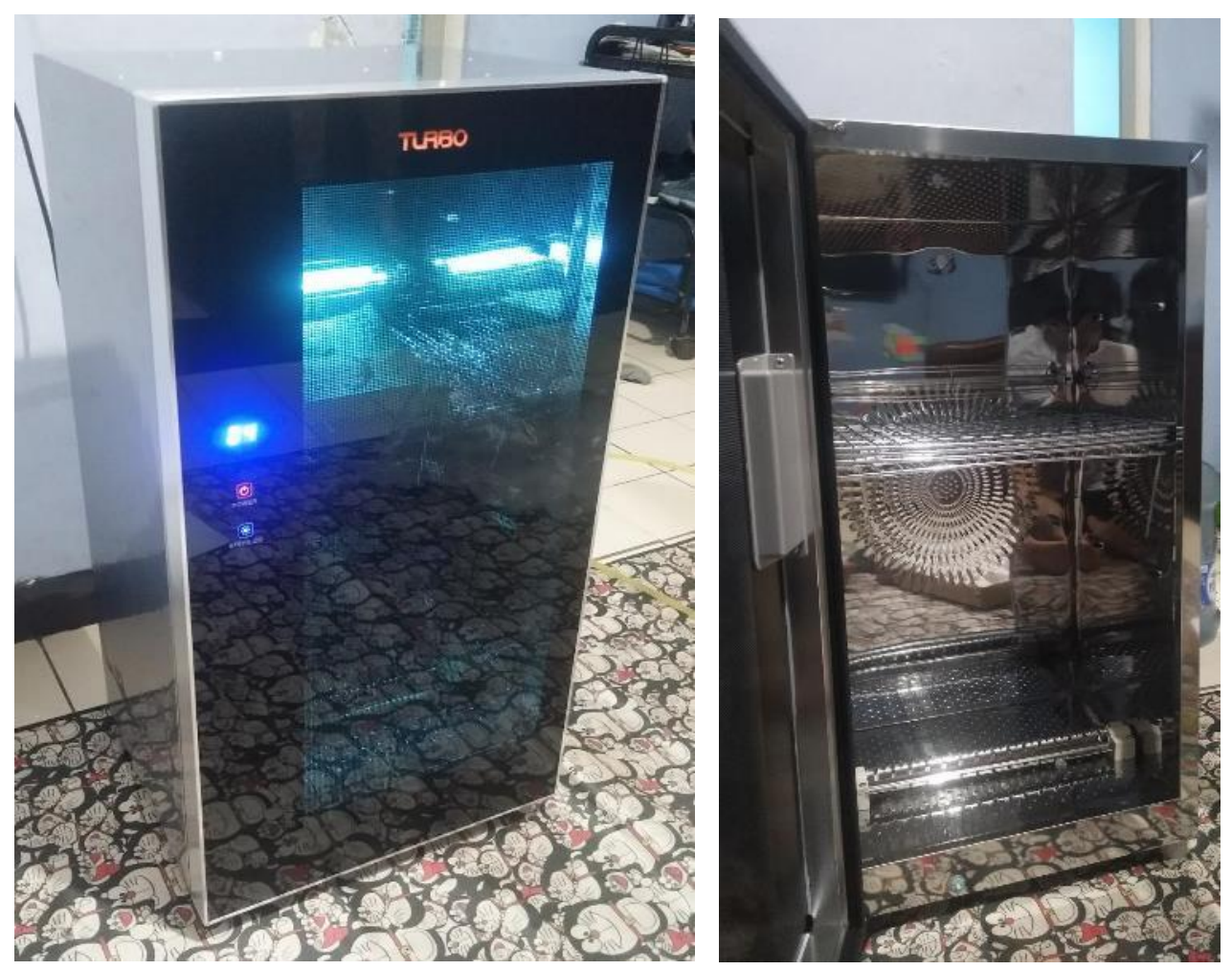

Gambar 5. UV-C locker satu tingkat 


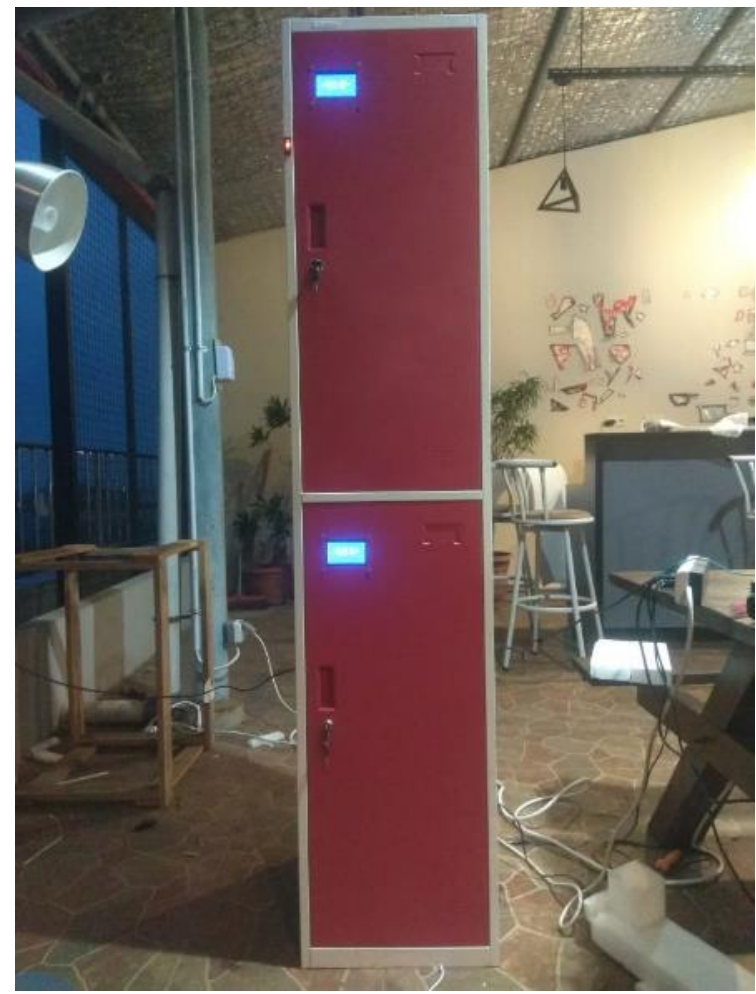

Gambar 6. Loker Dua Tingkat

\section{Hasil Kegiatan}

Feedback hasil kegiatan terlihat pada Tabel 1, di mana data pada tabel tersebut merupakan hasil rekapitulasi keseluruhan peserta. Mayoritas peserta setuju bahwa kegiatan ini telah terlaksana dengan baik dan sangat tepat sasaran, serta terasa manfaatnya pada peserta, yang ditunjukan dengan responden yang menjawab setuju dan sangat setuju sebesar $97 \%$.

Tabel 1. Rekapitulasi feedback seluruh peserta

\begin{tabular}{|l|c|c|c|c|}
\hline \multicolumn{1}{|c|}{ Penilaian Terhadap Kegiatan } & $\begin{array}{c}\text { Sangat Tdk } \\
\text { Setuju }\end{array}$ & $\begin{array}{c}\text { Tidak } \\
\text { Setuju }\end{array}$ & Setuju & $\begin{array}{c}\text { Sangat } \\
\text { Setuju }\end{array}$ \\
\hline $\begin{array}{l}\text { Kegiatan ini sudah sesuai dengan tujuan kegiatan itu } \\
\text { sendiri. }\end{array}$ & $0.0 \%$ & $0.0 \%$ & $14.3 \%$ & $85.7 \%$ \\
\hline $\begin{array}{l}\text { Kegiatan ini sudah sesuai dengan kebutuhan } \\
\text { masyarakat sasarnya. }\end{array}$ & $0.0 \%$ & $0.0 \%$ & $14.3 \%$ & $85.7 \%$ \\
\hline $\begin{array}{l}\text { Waktu pelaksanaan kegiatan ini relatif telah } \\
\text { mencukupi sesuai kebutuhan. }\end{array}$ & $0.0 \%$ & $14.3 \%$ & $0.0 \%$ & $85.7 \%$ \\
\hline $\begin{array}{l}\text { Dosen dan mahasiswa Universitas Telkom bersikap } \\
\text { ramah cepat dan tanggap membantu selama } \\
\text { kegiatan. }\end{array}$ & $0.0 \%$ & $0.0 \%$ & $14.3 \%$ & $85.7 \%$ \\
\hline $\begin{array}{l}\text { Masyarakat setempat menerima dan mengharapkan } \\
\text { kegiatan Universitas Telkom saat ini dan masa yang } \\
\text { akan datang. }\end{array}$ & $0.0 \%$ & $0.0 \%$ & $0.0 \%$ & $100.0 \%$ \\
\hline Jumlah "Sangat Setuju" + "Setuju" & \multicolumn{2}{|c|}{$97 \%$} & \\
\hline
\end{tabular}


Adapun komentar yang dikemukakan oleh responden terkait pelaksanaan adalah menginginkan pengembangan produk sehingga dapat melakukan steriisasi masker N95. Hal ini dikemukakan karena petugas kesehatan di rumah sakit sedang mengalami kesulitan pengadaan masker tersebut. Perlu diketahui, masker yang beredar di pasaran saat ini adalah maskernon medis, masker medis, dan KN95, yang efektivitasnya dibawah masker N95. Mengingat pihak kampus tidak memiliki perangkat deteksi virus, disarankan bekerja sama dengan UGM yang telah melakukan penelitian terlebih dahulu

\section{Kesimpulan}

Berdasarkan hasil kuisioner pada poin sebelumnya, terlihat bahwa kegiatan pengabdian masyarakat ini telah membantu masyarakat mitra sasar RSUD-KK adalah sebagai berikut.

a. Pemanfaatan Loker sterilisasi yang digunakan untuk tenaga medis yang berupa loker sterilisasi satu tingkat dan untuk pengunjung berupa loker sterlisasi dua tingkat.

b. Loker sterilisasi dibuat dengan sistem touchless untuk mengurangi kontak fisik dengan alat.

c. Masyarakat mitra menaggap bahwa kegiatan ini sesuai dengan tujuan dan kebutuhan masyarakat (jumlah setuju dan sangat setuju sebanyak 97\%).

\section{DAFTAR PUSTAKA}

[1] RSUD Kesehatan Kerja," [Online]. Available: http://rsudkk.jabarprov.go.id/. [Accessed 9 January 2021]

[2] World Health Organization, "Coronavirus disease (COVID-2019) situation reports," [Online]. Available: https://www.who.int/emergencies/diseases/novelcoronavirus-2019/situation-reports/. [Accessed 22 March 2020].

[3] Buonanno, M., Welch, D., Shuryak, I. et al. Far-UV-C light (222 nm) efficiently and safely inactivates airborne human coronaviruses. Sci Rep 10. 2020

[4] Rajiv, Suman, et. al. Sustainability of Coronavirus on Different Surfaces. Journal of Clinical and Experimental Hepatology. Volume 10, Issue 4. 2020. Pages 1-5

[5] Heßling M, Hönes K, Vatter P, Lingenfelder C. Ultraviolet irradiation doses for coronavirus inactivation - review and analysis of coronavirus photoinactivation studies. GMS Hyg Infect Control. 2020;15:Doc08. Published 2020 May 14.

[7] Heilingloh, Christiane Silke, et. al. Susceptibility of SARS-CoV-2 to UV irradiation. American Journal of Infection Control.Volume 48, Issue 10. 2020,Pages 1273-1275. 
[8] Lindblad, M., Tano, E., Lindahl, C., Huss, Fredrik. Ultraviolet-C decontamination of a hospital room: Amount of UV light needed. Burns. Volume 46, Issue 4, June 2020, Pages 842-849. 